\begin{tabular}{|c|l|}
\hline Title & In situ measurement of isoprene in the marine air and surface seawater from the western North Pacific \\
\hline Author(s) & Matsunaga, Sou; Mochida, Michihiro; Saito, Takuy a; Kawamura, Kimitaka \\
\hline Citation & $\begin{array}{l}\text { Atmospheric Environment, 36(39-40), 6051-6057 } \\
\text { https://doi.org/10.1016/S1352-2310(02)00657-X }\end{array}$ \\
\hline Issue Date & $2002-12$ \\
\hline Doc URL & http://hdl.handle.net/2115/10510 \\
\hline Type & article (author version) \\
\hline File Information & MatsunagaA E02416.pdf \\
\hline
\end{tabular}

Instructions for use 


\section{In situ measurement of isoprene in the marine air and surface seawater from the western North Pacific}

Sou Matsunaga $^{* a, b}$, Michihiro Mochida $^{\mathrm{a}}$, Takuya Saito ${ }^{\mathrm{a}, \mathrm{c}}$, Kimitaka Kawamura $^{\mathrm{a}}$

${ }^{a}$ Institute of Low Temperature Science, Hokkaido University, N19 W8, Kita-Ku, Sappro, 060-0819, Japan

${ }^{b}$ Graduate School of Environmental Earth Science, Hokkaido University, N10 W5, KitaKu, Sapporo, 060-0810, Japan

${ }^{c}$ Present address: Environmental Chemistry Division, National Institute for Environmental Studies, 16-2 Onogawa, Tsukuba, Ibaraki, 305-0053, Japan

*Corresponding author: e-mail matunaga@lowtem.hokudai.ac.jp

Fax $+81+11-706-7142$

Phone $+81+11-706-5504$ 


\begin{abstract}
Isoprene (2-methyl-1,3-butadiene) was measured on board of R/V Mirai for eight air samples and fourteen seawater samples collected in the western North Pacific during ACE-Asia campaign (from May 18 to May 26, 2001). The measurements were conducted in situ using a cryo focus/gas chromatography/mass spectrometry (Cryo/GC/MS). Concentrations of isoprene ranged from 7.2 to 111 parts-per-trillion (pptv) in the marine air, and ranged from below $1.2 \mathrm{pmol} \mathrm{L}^{-1}$ to $9.4 \mathrm{pmol} \mathrm{L}^{-1}$ in the seawater. Based on these results, sea-to-air emissions of isoprene were calculated to be from 16.4 to $24.6 \mathrm{nmol} \mathrm{m}^{-2} \mathrm{day}^{-1}$. The upper limits of the emission rates were also calculated to be from 3.2 to $30.4 \mathrm{nmol} \mathrm{m}^{-2}$ day $^{-1}$. Atmospheric isoprene concentrations cannot be explained only by the emission from the seawater. Thus the concentrations of isoprene in the marine air in western North Pacific should be significantly affected by terrestrial vegetational emission and subsequent long-range atmospheric transport of isoprene.
\end{abstract}

Keywords: sea-to-air emission, VOCs, long-range transport, cryo-focus, liquid $\mathrm{CO}_{2}$ 


\section{Introduction}

Non-methane hydrocarbons (NMHCs) of both biogenic and anthropogenic origin are important species in controlling the atmospheric chemistry. First, they react with atmospheric oxidants, and act as a sink of the oxidants such as $\mathrm{OH}$, which is the most important oxidant in the atmosphere. Second, some oxidation products of NMHCs are known to condense to form atmospheric particles. Such aerosol particles play important roles in scattering the solar radiation and acting as cloud condensation nuclei. Therefore, the emissions of NMHCs to the atmosphere may have important effects on a global scale climate system. Isoprene (2-methyl-1,3-butadiene) is highly reactive in the atmosphere and its emission rate in a global scale is the largest among all the NMHCs,

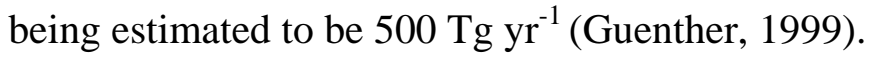

Isoprene is known to be emitted from terrestrial vegetation, however, recent studies revealed that isoprene is also released from the ocean (Bonsang et al., 1992, Yokouchi et al., 1999). The emission rate of isoprene from the ocean to the atmosphere

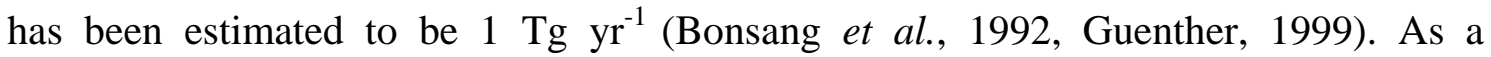
sparingly soluble gas, sea-to-air flux of isoprene can be calculated from its transfer velocity in the seawater, solubility and difference in the concentrations between the ambient air and surface seawater. Milne et al. (1995) reported isoprene emission rate in Florida coast, ranging from 9.51 to $101.2 \mathrm{nmol} \mathrm{m}^{-2}$ day $^{-1}$. Broadgate et al. (1997) reported the seasonal variation of isoprene emission rates $\left(1.4\right.$ to $\left.68 \mathrm{nmol} \mathrm{m}^{-2} \mathrm{day}^{-1}\right)$ in the North Sea and Southern Ocean.

Isoprene is known as the most important NMHC that affects the atmospheric chemistry in the terrestrial region. Although its emission and degradation in the continents are relatively well known by previous studies, there are only few reports about the emission rate and distribution of isoprene in the open ocean. Especially, the production and degradation balance of isoprene in the North Pacific have rarely been 
studied. In addition, the oceanic isoprene should mostly react with the oxidants such as $\mathrm{OH}$, ozone and chlorine atoms in the marine atmosphere (Tuazon and Atkinson, 1990; Atkinson, 1990; Keene et al., 1993; Ragains and Finlayson-Pitts, 1997), serving as a sink for the oxidants in the marine boundary layer. In this study, we report the distributions of isoprene concentrations in the marine atmosphere and surface seawater in the western North Pacific, and determined its sea-to-air fluxes.

\section{Experimental section}

\subsection{Sampling site and GC/MS System}

The sampling of marine air and seawater was conducted in the western North Pacific along the $146^{\circ} 25^{\prime} \mathrm{E}$ transect (from $30^{\circ} 45^{\prime} \mathrm{N}, 146^{\circ} 25^{\prime} \mathrm{E}$ to $35^{\circ} 45^{\prime} \mathrm{N}, 146^{\circ} 23^{\prime} \mathrm{E}$ ) during the cruise of R/V Mirai (MR01-K02, Japan Marine Science \& Technology Center) as part of ACE-Asia (Asian Pacific Aerosol Characterization Experiment) campaign (from May 18 to 26 , 2001). Figure 1 shows the map with the sampling sites. Eight air and fourteen seawater samples were analyzed in this study.

In order to avoid the potential degradation and production of NMHCs during a sample storage, in situ measurement is sometimes required for biogenic and reactive compounds such as isoprene in seawater. Hydrocarbon analysis using the cryo focus preconcentration system generally needs liquid $\mathrm{N}_{2}$ for cooling traps, however, there is a difficulty in using and loading the liquid $\mathrm{N}_{2}$ on a ship in the open ocean. We developed the cryo focus preconcentration system that does not require liquid $\mathrm{N}_{2}$, but needs only liquid $\mathrm{CO}_{2}$ as cooling media (see Figure 2). The cryo focus system coupled with GC/MS on R/V Mirai allowed us to measure in situ isoprene in the air and surface seawater in the open ocean. 


\subsection{Determination of isoprene in the air samples}

The marine air samples were collected into the pre-evacuated $6 \mathrm{~L}$ stainless steel canister (Silco-Can, RESTEC Corp., Bellefonte, PA), and pressurized to approximately 2 atm using Teflon bellows pump at compass deck of the ship (approximately $25 \mathrm{~m}$ above the sea level). The air samples were stored approximately 1.5 hour at room temperature, during which the atmospheric oxidants are considered to be destroyed on the surface of the canister. Thus oxidation of isoprene on the trap during the adsorption should be avoided.

The air samples were analyzed using a preconcentration/cryo focus/capillary gas chromatograph/mass spectrometer (Cryo/GC/MS) system on board, as illustrated in Figure 2. The preconcentration unit (GAS 30, DKK corporation, Tokyo, Japan) is consisted of adsorption trap (60 mg of Carbotrap, SUPELCO, Bellefonte, PA), capillary trap (top $5 \mathrm{~cm}$ of capillary GC column) and two switching valves. The two traps were designed to be cooled down by liquid $\mathrm{CO}_{2}$. A $750 \mathrm{~mL}$ of sample air was drawn from the canister through a water trap (approximately $\left.5 \mathrm{~g} \mathrm{Mg}\left(\mathrm{ClO}_{4}\right)_{2}\right)$ and then adsorption trap, the later had been cooled to approximately $-50{ }^{\circ} \mathrm{C}$ by liquid $\mathrm{CO}_{2}$. Adsorption of isoprene onto the former trap was checked to be negligible. The latter trap was then heated to $150{ }^{\circ} \mathrm{C}$ in order to desorb the isoprene that was trapped in the adsorption trap, and then transferred to the capillary cryo focus trap that had been cooled down to approximately $-70{ }^{\circ} \mathrm{C}$ by liquid $\mathrm{CO}_{2}$. Finally, the capillary trap was heated to $175{ }^{\circ} \mathrm{C}$, and the isoprene was transferred into GC/MS (Finnigan MAT GCQ). Helium was used as a carrier gas. Compounds in the sample air were separated on a capillary column $\left(\mathrm{Al}_{2} \mathrm{O}_{3}\right.$ PLOT, Chrompack, $0.32 \mathrm{~mm}$ i.d. $\times 50 \mathrm{~m}$ long). Analysis of one air sample was completed within 30 minutes.

\subsection{Determination of isoprene in the seawater samples}


Surface seawater samples were collected from $10 \mathrm{~m}$ in water depth using Niskin bottles installed in a CTD system. The seawaters were transferred into $730 \mathrm{~mL}$ glass bottles immediately after the CTD was recovered on the ship. The samples were analyzed within 30 minutes after the collection. The seawater sample was fully removed from the bottle into a $1 \mathrm{~L}$ glass cell in the gas extraction system (Figure 3). Then, the isoprene in the sample water was stripped with a pure helium bubble flow $\left(50 \mathrm{~mL} \mathrm{~min}{ }^{-}\right.$ ${ }^{1}$ ) for 30 minutes. The helium gas containing isoprene was drawn through the first water trap (approximately $\left.1 \mathrm{~g} \mathrm{Mg}\left(\mathrm{ClO}_{4}\right)_{2}\right)$ and then transferred to the preconcentration unit of a capillary GC as mentioned above. Analysis of one seawater sample needed 45 minutes.

\section{Results and discussion}

\subsection{Concentrations of isoprene in the marine air and surface seawater}

Table 1 presents the analytical results of isoprene in the western North Pacific. Concentrations of atmospheric isoprene ranged from 7.2 to 111 pptv (average, 45.6 pptv). The seawater concentrations ranged from the below detection limit (the detection limit was $1.2 \mathrm{pmol} \mathrm{L}-1$ ) to $9.4 \mathrm{pmol} \mathrm{L}^{-1}$, with the average concentration of $3.1 \mathrm{pmol} \mathrm{L}^{-1}$. Figure 4 presents the isoprene concentrations in the surface seawater samples collected at the water depth of $10 \mathrm{~m}$. The averaged daytime concentration of isoprene $(5.6 \mathrm{pmol}$ $\left.\mathrm{L}^{-1}\right)$ exceeded that of nighttime $\left(2.7 \mathrm{pmol} \mathrm{L}^{-1}\right.$; see Table 1$)$. This suggests that isoprene production by marine biological processes was greater in daytime (see Table 1). In contrast, the results of air samples showed that the nighttime averaged concentration of isoprene exceeded that of daytime. 
If isoprene could be assumed to be in equilibrium between the air and surface seawater, its concentration in the seawater should be equivalent to the product of Henry's law constant $\left(\mathrm{K}_{\mathrm{H}}\right)$ and the partial pressure of isoprene $\left(\mathrm{P}_{\text {isoprene }}\right)$ in the air. Table 1 shows the average and median of the products $\left(\mathrm{P}_{\text {isoprene }} \times \mathrm{K}_{\mathrm{H}}\right)$ for the different sampling sites. The average concentration in the seawater $\left(3.1 \mathrm{pmol} \mathrm{L}^{-1}\right)$ exceeded the product $\left(\mathrm{P}_{\text {isoprene }} \times \mathrm{K}_{\mathrm{H}} ; 1.3 \mathrm{pmol} \mathrm{L}{ }^{-1}\right)$. This indicates that the isoprene flux was directed from the sea surface to the atmosphere.

\subsection{Emission rate of isoprene}

The sea-to-air flux of isoprene $\left(F\right.$ in $\left.\mathrm{mol} \mathrm{m}^{-2} \mathrm{~s}^{-1}\right)$ can be calculated by the following equation:

$$
F=k_{L}\left(C_{w}-K_{H} P_{\text {isoprene }}\right)
$$

, where $k_{L}$ is the liquid phase transfer velocity. $C_{w}, K_{H}$ and $P_{\text {isoprene }}$ are defined as concentration in surface seawater, Henry's law constant and partial pressure of isoprene, respectively. Wanninkhof (1992) has proposed a relationship of $k_{L}$ in $\mathrm{m} \mathrm{s}^{-1}$ with wind speed $U\left(\mathrm{~m} \mathrm{~s}^{-1}\right)$ and Schmidt number $S c$ as follows.

$$
k_{L}=2.778 \times 10^{-6}\left(0.31 U^{2}(S c / 660)^{-1 / 2}\right)
$$

Schmidt number of isoprene was adapted from Milne et al. (1995) for the calculation of isoprene emission rate. Table 2 presents wind speed at the sampling site and the emission rates of isoprene from the ocean. The emission rates (16.4-24.6 nmol $\mathrm{m}^{-2}$ day $^{-1}$ ) were lower than the previous results (see Table 2) reported in Florida coast, North Sea and Southern Ocean (Milne et al., 1995; Broadgate et al., 1997). This suggests that the biological production of isoprene in the western North Pacific may be lower than the oceans studied previously. The upper limits of the emission rate of isoprene can be calculated on the assumption that concentrations of isoprene in the 
marine air were zero. The upper limits of the emission rates were also lower than those of the previous reports (see Table 2).

\subsection{Source of isoprene in the marine air}

The height of the marine boundary layer (MBL) at the sampling site was approximately $1000 \sim 1200 \mathrm{~m}$ (a personal communication with K. Miura, Tokyo University of Science). Assuming that the marine air in the MBL was convected within half day, the lifetime of isoprene was 2 hours, we estimated the emission rate of isoprene from sea surface to be $20 \mathrm{nmol} \mathrm{m}^{-2} \mathrm{day}^{-1}$. This means that the daytime concentration of isoprene derived only from the ocean is very low (0.016 pptv). Therefore we concluded that the sea-to-air emission of isoprene did not contribute to the measured concentrations (ca. 50 pptv) in the western North Pacific.

The result of back trajectory analysis (see Figure 5) and radon concentration (a personal communication with K. Miura) suggested that most of the air parcels at the sampling site had passed through the terrestrial regions in Asia 1 to 5 days before the sampling. The concentration of terrestrial isoprene would decrease to 50 pptv (nearly equal to the observed concentration in the marine air) within 5 days on the assumption that initial concentration was $1 \mathrm{ppbv}$ and averaged daytime concentration of $\mathrm{OH}$ was $5 \times 10^{4}$ to $1 \times 10^{5}$ molecules $\mathrm{cm}^{-3}$. These assumptions are realistic and do not contradict to the observed concentrations of isoprene in the marine air in this study. Thus, the isoprene in the marine air ( 7.2 to $111 \mathrm{pptv})$ were probably significantly influenced by the terrestrial emission and long-range atmospheric transport in the western North Pacific.

\section{Conclusion}


Concentrations of isoprene in both marine air and surface seawater have been in situ measured in the western North Pacific during an early summer, and the isoprene sea-to-air fluxes were calculated. The isoprene flux in the western North Pacific was

estimated to be $20 \mathrm{nmol} \mathrm{m}^{-2}$ day $^{-1}$. Although this is 5 times lower than the isoprene flux estimated on a global scale in the previous modeling study $\left(110 \mathrm{nmol} \mathrm{m}{ }^{-2}\right.$ day $^{-1}$, Guenther, 1999), the results are consistent with the general knowledge that the biological productivity in the studied area (open ocean) was lower than that of the global average. Considering low emission rates of isoprene from the ocean, we suggest that atmospheric isoprene in the western North Pacific is mostly derived from terrestrial regions in Asia. In situ measurement of biogenic reactive compounds such as isoprene in the seawater sample allowed us to estimate the accurate the sea-to-air emission rate of such gases.

\section{Acknowledgements}

We thank the captain and clues of R/V Mirai (MR01-K02), Japan Marine Science \& Technology Center. We also thank Dr. Shungo Kato (Research Center for Advanced Science and Technology, The University of Tokyo) for valuable discussion and Mr. Katsunori Sagishima (Marine Works Japan) for maintenance of the GC/MS. This study was in part supported by the Grant-in-Aid for Scientific Research of Japan Society for the Promotion of Science (No. 07109) and Japanese Ministry of Education, Science, Sports and Culture (No. 10354009). 


\section{References}

Atkinson, R., 1990. Gas-phase tropospheric chemistry of organic compounds: A review. Atmospheric Environment 24A, 1-41.

Bonsang, B., Polle, C., Lambert, G., 1992. Evidence for marine production of isoprene. Geophysical Research Letters 19, 1139-1132.

Broadgate, W. J., Liss, P. S., Penkett, S. A., 1997. Seasonal emissions of isoprene and other reactive hydrocarbon gases from the ocean. Geophysical Research Letters 24, $2675-2678$.

Guenther, A., Hewitt, C. N., Erickson, D., Fall, R., Geron, C., Graedel, T., Harley, P., Klinger, L., Lerdau, M., McKay, W. A., Pierce, T., Scholes, B., Steinbrecher, R., Tallamraju, R., Taylor, J., Zimmerman, P. A, 1995. Global model of natural volatile organic compound emissions. Journal of Geophysical Research 100, 8873-8892.

Guenther, A., "Modeling Biogenic Volatile Organic Compound Emissions to the Atmosphere," Ch. 3, pp. 97-118. In Reactive Hydrocarbons in the Atmosphere, Academic Press, San Diego, 1999.

Karl, T., Yeretzian, C., Jordan, A., Lindinger, W., Dynamic measurements of Henry's law constants using proton-transfer-reaction mass-spectrometry (PTR-MS). submitted.

Keene, W. C., Maben, J. R., Pszenny, A. A. P., Galloway, J. N., 1993. Measurement technique for inorganic chlorine gases in the marine boundary layer. Environ. Sci. Technol. 27, 866-874. 
Milne, P. J., Riemer, D. D., Zika, R. G., Brand, L. E., 1995. Measurement of vertical distribution of isoprene in surface seawater, its chemical fate, and its emission from several phytoplankton monocultures. Marine Chemistry 48, 237-244.

Ragains, M. L., Finlayson-Pitts, B. J., 1997. Kinetics and mechanism of the reaction of $\mathrm{Cl}$ atoms with 2-methyl-1,3-butadiene (Isoprene) at 298 K. J. Phys. Chem. A. 101, $1509-1517$.

Tuazon, E. C., Atkinson, R., 1990. A product study of the gas-phase reaction of isoprene with the $\mathrm{OH}$ radical in the presence of $\mathrm{NO}_{\mathrm{x}}$. International Journal of Chemical Kinetics 22, 1221-1236.

Wanninkhof, R., 1992. Relationship between wind speed and gas exchange over the ocean. Journal of Geophysical Research 97, 7373-7382.

Yokouchi, Y., Li, H. J., Machida, T., Aoki, S., Akimoto, H., 1999. Isoprene in the marine boundary layer (Souheast Asian Sea, eastern Indian Ocean, and Southern Ocean): comparison with dimethyl sulfide and bromoform. Journal of Geophysical Research 104, 8067-8076. 
Figure 1 Sampling sites of the seawater samples (opened squares) and air samples (solid circles) collected in the western North Pacific (May 18 to 26, 2001).

Figure 2 An outline of the preconcentration system interfaced to capillary GC/MS.

Figure 3 An outline of the purge and trap system for isoprene in the seawater samples. This system is interfaced to cryo focus capillary GC/MS (see Figure 2).

Figure 4 The concentrations of isoprene in the seawater and air samples at daytime (06:00-19:00, local time) and nighttime (19:00-06:00) in the $146^{\circ} 25^{\prime} \mathrm{E}$ transect of the western North Pacific. Black (nighttime) and white (daytime) bar mean the calculated concentrations of isoprene based on the Henry's law constant $\left(\mathrm{K}_{\mathrm{H}}\right)$ and the partial pressure of isoprene ( $\mathrm{P}_{\text {isoprene, }}$, see the text for details).

Figure 5 The result of back trajectory analysis. Opened circles are sampling sites of the atmospheric isoprene, solid lines are calculated trajectory of the air parcel before 5 days of the sampling. The trajectory data was obtained from HYSPLIT model provided by NOAA Air Resources Laboratory. 
Fig. 1 (Matsunaga et al.)

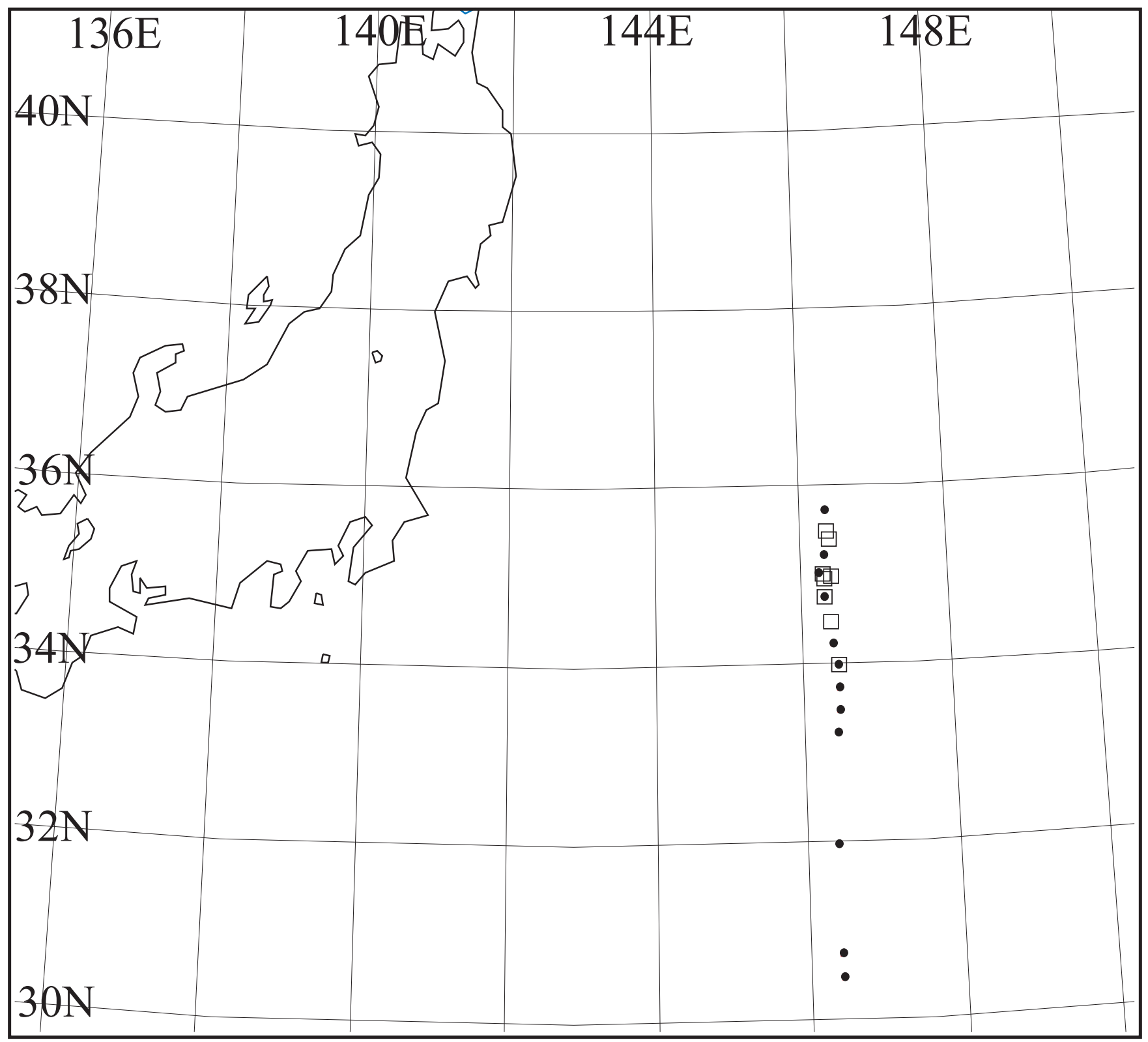




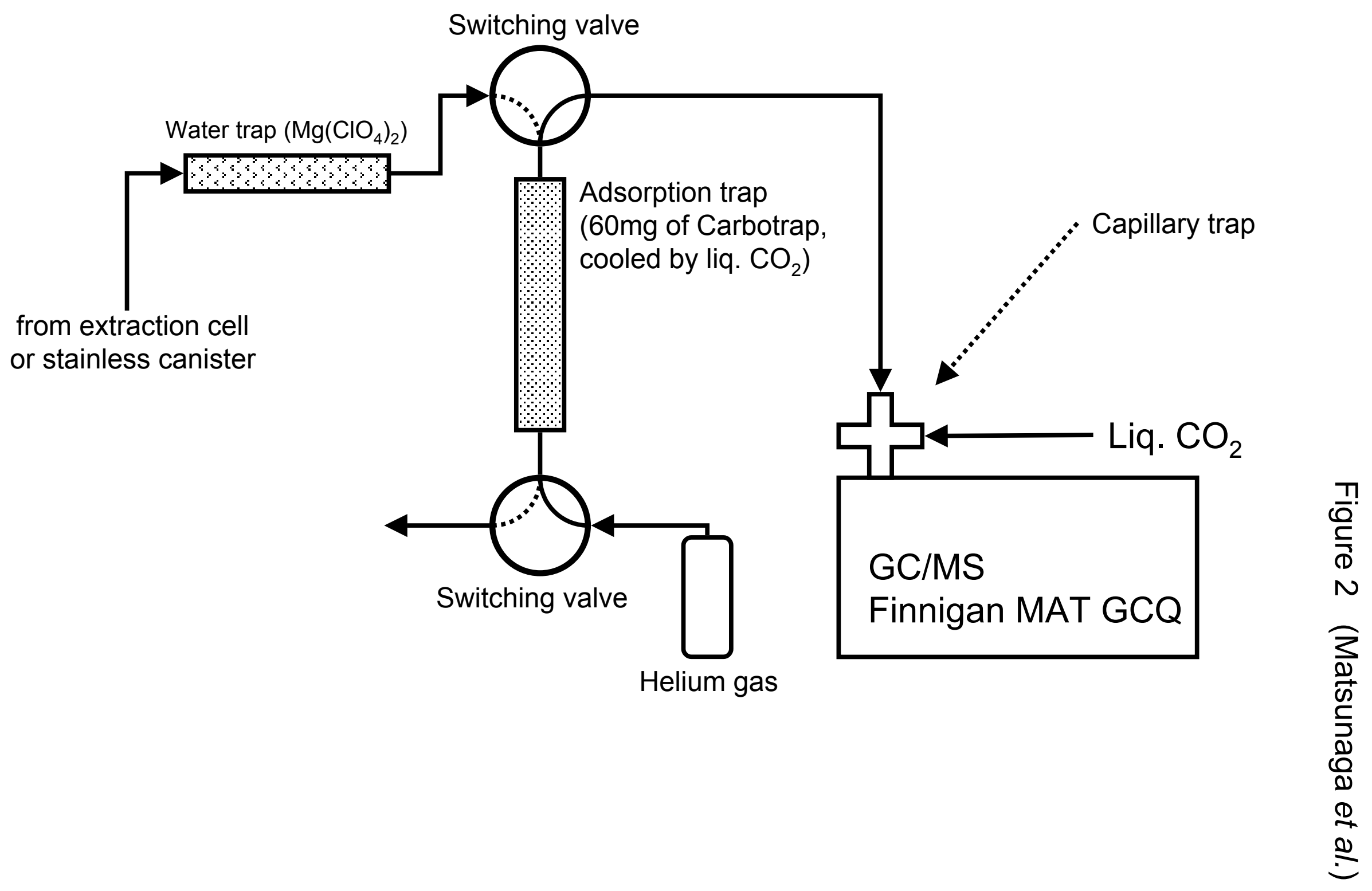




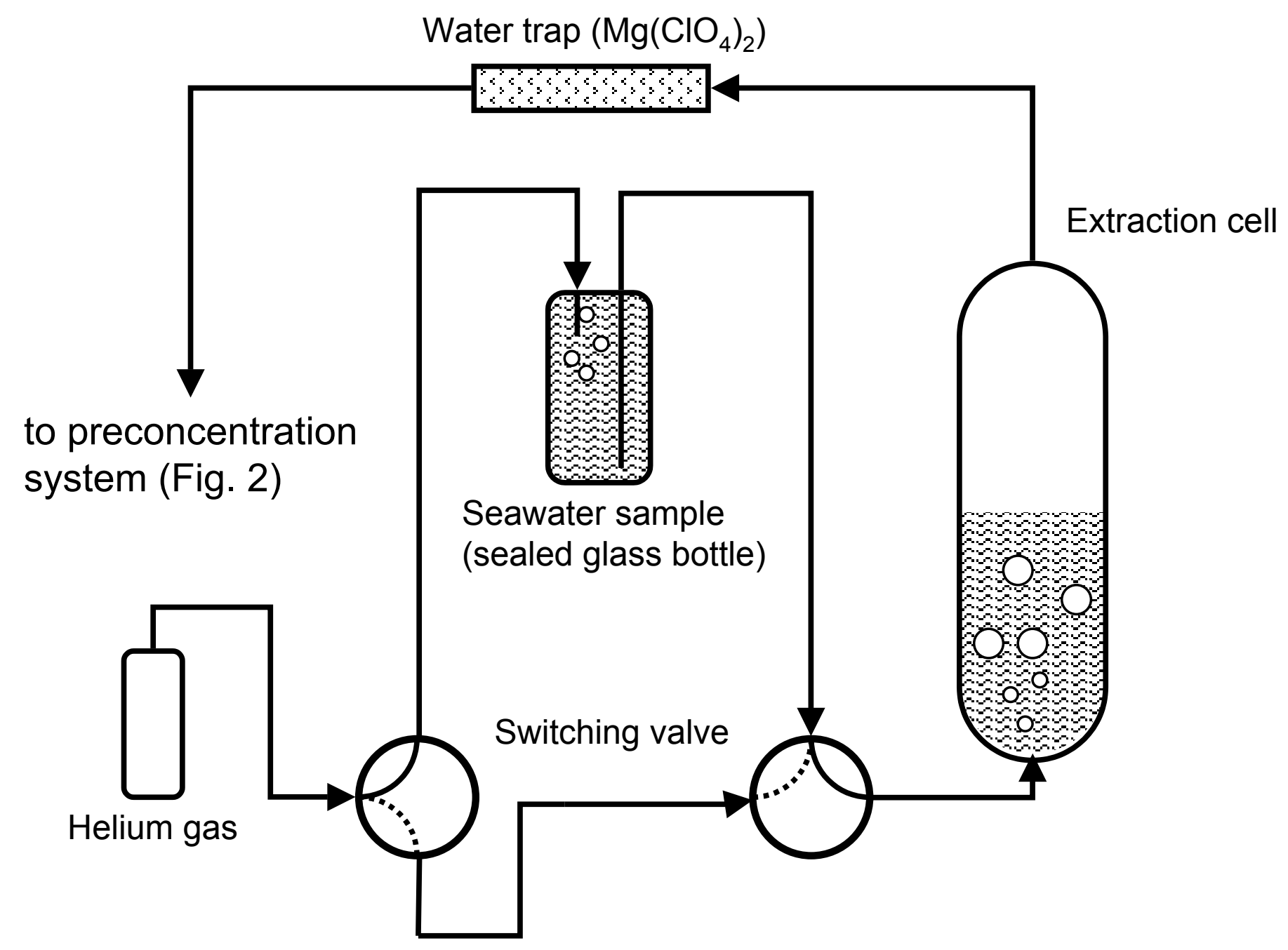

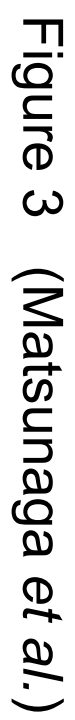


Figure 4 (Matsunaga et al.)

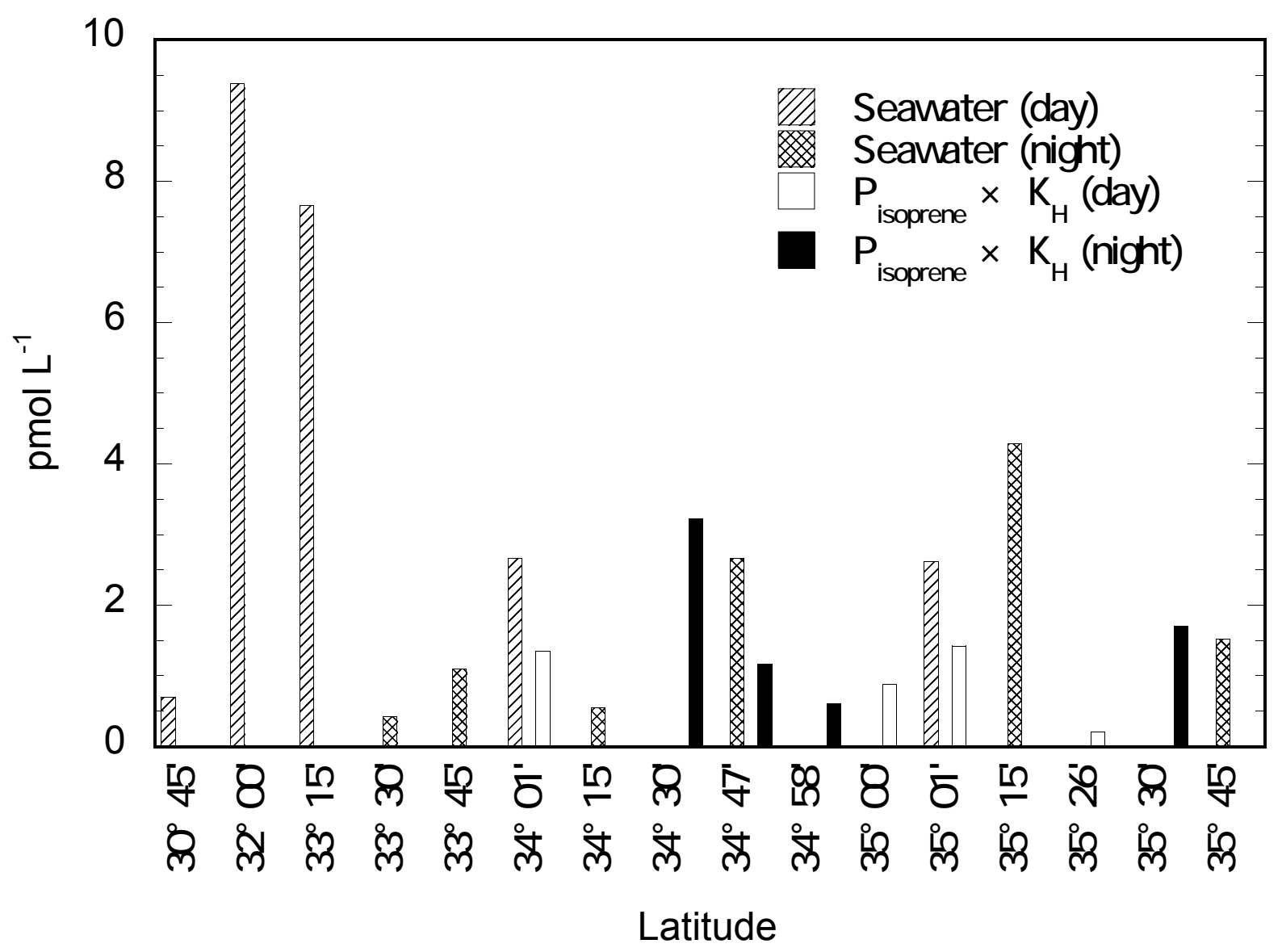


Figure 5 (Matsunaga et al.)

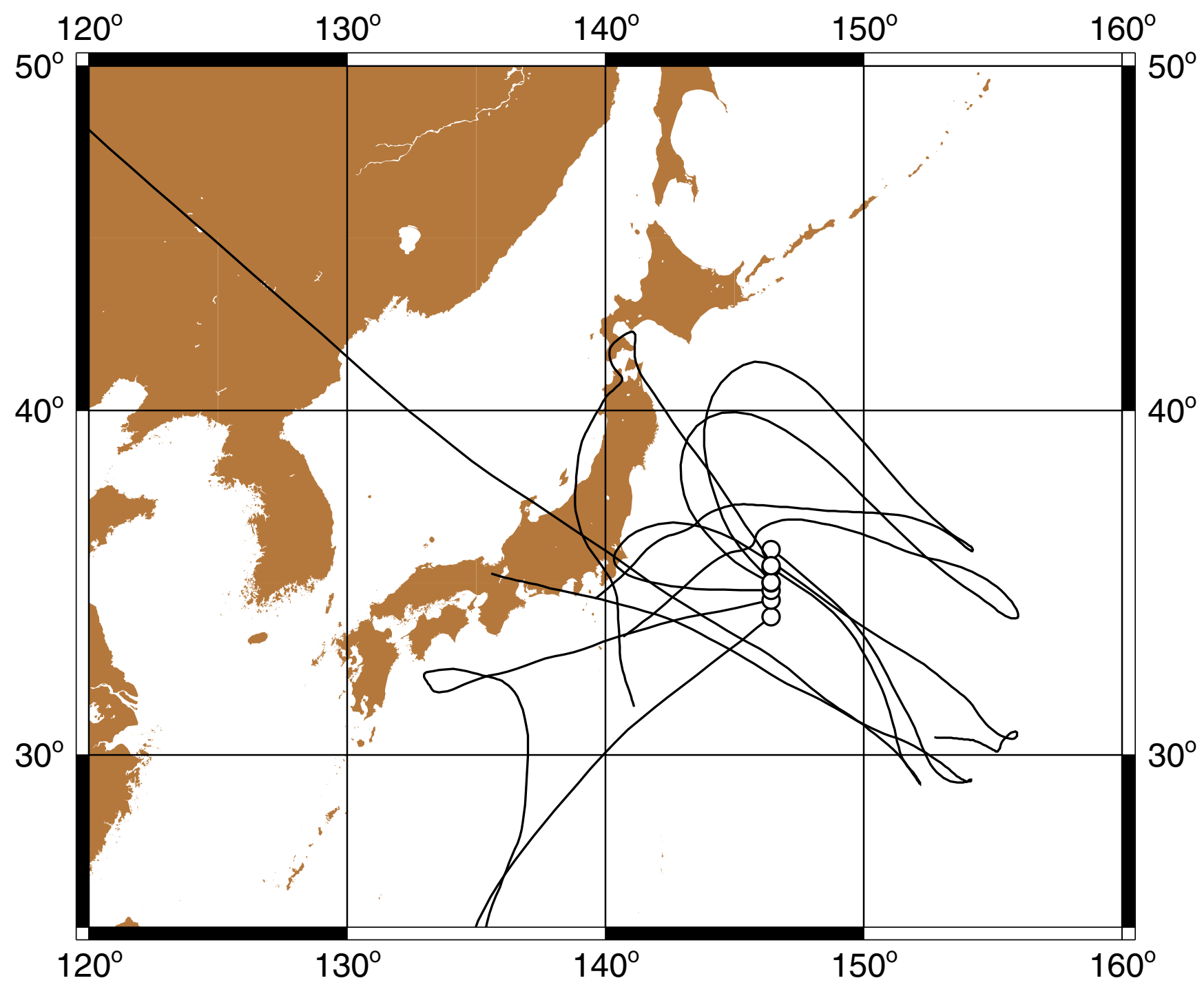


Table 1 Concentrations of isoprene in the marine air and surface seawater in the western North Pacific along the $146^{\circ} 25^{\prime} \mathrm{E}$ transect.

\begin{tabular}{|c|c|c|c|c|}
\hline Time & Latitude & $\frac{\text { Air }}{\text { (nntv) }}$ & $\frac{\mathbf{P}_{\text {isoprene }} \times \mathbf{K}_{\mathbf{H}}}{\left(\mathrm{nmol} \mathrm{L}^{-1}\right)}$ & $\frac{\text { Seawater }}{\left(\text { pmol L } L^{-1}\right)}$ \\
\hline 18-May 12:45 & $30^{\circ} 45^{\prime} \mathrm{N}$ & & & BDL \\
\hline 19-May 12:18 & $32^{\circ} 00^{\prime} \mathrm{N}$ & & & 9.4 \\
\hline 20-May 13:00 & $33^{\circ} 15^{\prime} \mathrm{N}$ & & & 7.7 \\
\hline 20-May 20:00 & $33^{\circ} 30^{\prime} \mathrm{N}$ & & & BDL \\
\hline 21-May 22:30 & $33^{\circ} 45^{\prime} \mathrm{N}$ & & & BDL \\
\hline 23-May 13:30 & $35^{\circ} 26^{\prime} \mathrm{N}$ & 7.2 & 0.2 & \\
\hline 23-May 18:30 & $34^{\circ} 58^{\prime} \mathrm{N}$ & 20.8 & 0.6 & \\
\hline 24-May 15:40 & $34^{\circ} 01^{\prime} \mathrm{N}$ & 46.4 & 1.3 & $2.7^{*}$ \\
\hline 24-May 20:30 & $34^{\circ} 15^{\prime} \mathrm{N}$ & & & BDL \\
\hline 25-May 00:48 & $34^{\circ} 30^{\prime} \mathrm{N}$ & 111 & 3.2 & \\
\hline 25-May 06:05 & $34^{\circ} 47^{\prime} \mathrm{N}$ & 40.3 & 1.2 & $2.7^{*}$ \\
\hline 25-May 10:47 & $35^{\circ} 00^{\prime} \mathrm{N}$ & 30.5 & 0.9 & \\
\hline 25-May 13:52 & $35^{\circ} 01^{\prime} \mathrm{N}$ & 49.1 & 1.4 & \\
\hline 25-May 14:50 & $35^{\circ} 01^{\prime} \mathrm{N}$ & & & 2.6 \\
\hline 25-May 20:30 & $35^{\circ} 15^{\prime} \mathrm{N}$ & & & 4.3 \\
\hline 26-May 01:05 & $35^{\circ} 30^{\prime} \mathrm{N}$ & 58.8 & 1.7 & \\
\hline 26-May 06:00 & $35^{\circ} 45^{\prime} \mathrm{N}$ & & & 1.5 \\
\hline Maximum & & 111 & 3.2 & 9.4 \\
\hline Minimum & & 7.2 & 0.2 & BDL \\
\hline Average & & 45.6 & 1.3 & 3.1 \\
\hline Median & & 43.4 & 1.3 & 2.7 \\
\hline \multicolumn{2}{|c|}{ Average (daytime) } & 30.8 & 0.9 & 5.6 \\
\hline \multicolumn{2}{|c|}{ Median (daytime) } & 30.5 & 0.9 & 5.2 \\
\hline \multicolumn{2}{|c|}{ Average (night time) } & 70.1 & 2.0 & 2.7 \\
\hline \multicolumn{2}{|c|}{ Median (nighttime) } & 58.8 & 1.7 & 2.7 \\
\hline
\end{tabular}

BDL: below detection limit. Detection limit for air sample and seawater sample were 5 pptv and $1.2 \mathrm{pmol} \mathrm{L}^{-1}$, respectively. Henry's law constant $\mathrm{K}_{\mathrm{H}}$ for isoprene was adapted from Karl et al..

*: The data were used for the calculation of sea-to-air flux of isoprene (see Table 2). 
Table 2 Estimated emission rate of isoprene from the ocean.

\begin{tabular}{|c|c|c|c|c|c|}
\hline Date & Time & Location & Wind speed $\left(\mathrm{m} \mathrm{s}^{-1}\right)$ & Flux $\left(\right.$ nmol m${ }^{-2}$ day $\left.^{-1}\right)$ & Reference \\
\hline 19-May & $12: 18$ & western North Pacific & 3.6 & $7.7^{*}$ & this study \\
\hline 20-May & 13:00 & western North Pacific & 7.1 & $24.6^{*}$ & this study \\
\hline 24-May & $15: 40$ & western North Pacific & 10.4 & $16.4\left(18.6^{*}\right)$ & this study \\
\hline 25-May & $6: 05$ & western North Pacific & 13.3 & $24.6\left(30.4^{*}\right)$ & this study \\
\hline 25-May & $14: 50$ & western North Pacific & 7.2 & $8.6^{*}$ & this study \\
\hline 25-May & $20: 30$ & western North Pacific & 3.4 & $3.2^{*}$ & this study \\
\hline 26-May & 06:00 & western North Pacific & 7.6 & $5.6^{*}$ & this study \\
\hline 10-Sep & $15: 45$ & Florida Straits & 3.33 & 38.6 & Milne et al. \\
\hline 10-Sep & $18: 30$ & Florida Straits & 1.28 & 12.6 & Milne et al. \\
\hline 10-Sep & $22: 00$ & Florida Straits & 2.01 & 9.5 & Milne et al. \\
\hline 11-Sep & $8: 30$ & Florida Straits & 5.00 & 39.1 & Milne et al. \\
\hline 12-Sep & $16: 00$ & Florida Straits & 4.49 & 101.2 & Milne et al. \\
\hline 13-Sep & $5: 00$ & Florida Straits & 7.99 & 65.5 & Milne et al. \\
\hline 13-Sep & $8: 00$ & Florida Straits & 7.11 & 71.8 & Milne et al. \\
\hline & & North Sea & & $24.4^{* *}$ & Broadgate et al. \\
\hline
\end{tabular}

: Calculated upper limit of the isoprene flux. ${ }^{* *}$ : Annual mean value. 